\title{
The Front National at the polls: Transformational elections or the status quo reaffirmed?
}

\author{
James Shields
}

School of Languages and Social Sciences, Aston University, Birmingham

B4 7ET, UK

\begin{abstract}
There is a widespread sense that the Front National (FN) came of age in 2014 as a challenger for power in France. The municipal and European elections appeared to herald a transformation in the party's development and prospects, demonstrating its capacity to compete as a major player at subnational and supranational levels following strong performances at the national level in the presidential and legislative elections of 2012. This article takes a critical view of that assessment. It argues that the FN in 2014 made significant progress but that the apparent surge of support for the party in these elections belies fundamental weaknesses in the depth and range of its electoral capacities and in its prospects for transforming itself into a party of government. These weaknesses were again evident in the departmental elections of 2015, confirming that the FN has not succeeded in ending bipolarisation and imposing a genuinely tripartite structure on French politics. Far from being the 'first party of France' and 'at the gates of power', the FN is still consigned primarily to a role of spoiler, with its progression stalled by institutional obstacles, electoral limitations and a political containment which it remains powerless to overcome.
\end{abstract}

\section{Keywords}

French elections; Front National; municipal elections; European elections; departmental elections; bipolarisation 


\section{Introduction}

To judge by newspaper headlines, online commentaries and the pronouncements of politicians, 2014 was a year when the tectonic plates of French politics shifted. The municipal elections of March were greeted by a profusion of portentous natural images - a 'seismic event', a 'shock', a 'thunderclap', an 'earthquake' (Fressoz, 2014; Galiero, 2014a; Lichfield, 2014; La Tribune, 2014). In similar vein, the European elections of May saw a 'seismic' shift in French politics, a 'tsunami' and 'tidal wave', a 'big bang' bringing in its wake 'profound changes' to 'devastate the French political landscape' (Oliveau, 2014; Jaxel-Truer and Wieder, 2014; Le Monde, 2014a).

The inspiration for these images in both elections was the performance by the Front National (FN), which won control of 11 town and city councils in March then came top of the European poll in May with almost 25 per cent of the vote and the largest share (24) of France's 74 seats in the European Parliament. This unprecedented success was described by Jean-Luc Mélenchon of the far-left Front de Gauche as a 'volcanic eruption' and by Prime Minister Manuel Valls as 'a shock, an earthquake' sending its effects across France's entire political establishment (Le Figaro, 2014; Garat, 2014).

This representation of the far right as an irresistible political force is not new; nor is it confined to France. A burgeoning academic literature has begun to focus on the effects of media projection on the image and fortunes of far-right parties in different European countries (Mazzoleni et al, 2003; Walgrave and de Swert, 2004; Boomgaarden and Vliegenthart, 2007; Akkerman, 2011; Ellinas, 2014). The often disproportionate coverage by the media masks a paradox: while the mainstream media are almost universally antipathetic to far-right parties, they enter a pact of mutually beneficial dependence: the media need 'the story' and the parties need the attention. What these parties stand to gain from a raised public profile is an increased perception of their importance and a greater likelihood of being 'taken seriously' (Bos et al, 2011: 197); and the more powerful the media projection, the more their legitimacy is arguably bolstered (Kallis, 2013: 227). At what point, we might then ask, does proclaiming the far right's strength become a 'self-fulfilling prophecy' (Mondon, 2015: 145)?

The media in France have long indulged in such inflated reporting of the FN; there is little here that is new bar the degree of hyperbole deployed. What marks more of a change is the 
shift in the academic literature from perceiving the FN as a nuisance party (Shields, 1997), a marginal force confined to a role of oppositional protest (Perrineau, 1993, 2003; Fourquet, 2008), to asking whether it might be becoming a potential contender for power. In a study of French political parties published in 1989, Colette Ysmal summed up the FN's 'destiny' as an outsider party 'obliged to distinguish itself at all costs from the forces of "government"'. By this analysis, and others like it, the FN was the antithesis of a party of government, defined in its very essence by not being one and inviting the question of how long it could last in such oppositional isolation (Ysmal, 1989: 149-150; Perrineau, 1993: 159).

Since the change of leadership in 2011 and the subsequent upturn in the party's electoral fortunes, analysts have posed quite different questions. Has the FN under Marine Le Pen transformed itself from an anti-system outsider to a 'mainstreamed' political force and 'Republican democratic contender' (Mondon, 2014)? Has the political landscape in France, for so long subject to the iron law of bipolarisation, become effectively tripartite, or do the institutional constraints of France's majoritarian system remain as firmly embedded as ever (de Voogd, 2014; Revault d'Allonnes, 2015; Hausalter, 2015)? Or, again, is 'a particular synthesis between old and new politics' now at work to reshape France's political landscape by gradual evolution rather than any seismic event (Tiberj, 2013: 71)? And, in the space opened up by this evolution, has a party historically consigned to exclusion now come of age as a genuine challenger for power (Dézé, 2012; Perrineau, 2014)?

This article approaches these questions through an analysis of three recent elections in France: the municipal and European elections of 2014 and the departmental elections of 2015. It takes a critical view of the too-frequent tendency to overstate the FN's advance and the impact it is purported to exert in redrawing the contours of French politics. It argues that the FN since 2012 has made significant progress but that the apparent surge of support for the party in these elections belies fundamental weaknesses in the depth and range of its electoral capacities and in its prospects for transforming itself into a party of government. The FN, it concludes, has not succeeded in ending bipolarisation and imposing a genuinely tripartite structure on French politics. Far from being the 'first party of France' (Rouart, 2014) and 'at the gates of power' (Bretton, 2015), it is still consigned primarily to a role of spoiler, with its progression stalled by institutional obstacles, electoral limitations and a political containment which it remains powerless to overcome. 


\section{The Municipal elections - a 'seismic event'?}

In March 2014, the FN entered local government. From holding no elected office, it secured control of 11 municipalities with a combined population of some 400,000 and a six-year mandate to implement its policies. These municipal elections were a success not only in terms of executive gains but in terms, too, of the 1,544 council seats won across France, 483 of those on the first ballot. This was well in advance of the 1,000 seats that had been the party's declared target and incomparably more than the 59 seats it had won in the previous municipal elections of 2008. Fielding a record 585 lists in communes of over 1,000 inhabitants (compared with 122 lists in 2008), it contested over 400 towns of more than 9,000 inhabitants (up from 106 in 2008) (Brouard and Foucault, 2014). It qualified for run-offs in 321 municipalities, of which it contested 317 , averaging 14.8 per cent where present in the first round (compared with 5.5 per cent in 2008) and 17.2 per cent in the second.

These results were a vindication of the strategic decision to target FN lists in municipalities where the party had performed well in the 2012 presidential and legislative elections and stood the strongest chance of getting councillors elected. These lay mainly in Mediterranean littoral departments where FN strength was long-established and in departments scarred by post-industrial restructuring across the north and north-east where the FN had made deep inroads into once left-wing working-class territory (Crépon, 2012). The most significant town and city councils captured were the $7^{\text {th }}$ sector of Marseille with over 150,000 inhabitants, Béziers (over 71,000) and Fréjus (over 52,000), all three located in the FN's Mediterranean heartlands. Other smaller towns won were Beaucaire, Le Pontet, Cogolin and Le Luc in the south and Hénin-Beaumont, Villers-Cotterêts, Mantes-la-Ville and Hayange in the north.

In some locations, most notably the steel-manufacturing town of Hayange in the Moselle department and the former coalmining town of Hénin-Beaumont in the Pas-de-Calais, the FN's wins bore the imprint of the party's policy turn towards a markedly left-leaning, protectionist agenda pledging lower taxes, income redistribution and the preservation of public services. As evidence of the FN's growing appeal across the right-left divide, most of its councils were captured from the left, not from the right - four from the Socialist Party (Hayange, Mantes-la-Ville, Villers-Cotterêts, Marseille-7th sector) and two from the 'divers 
gauche' (Hénin-Beaumont, Le Luc), with Marseille's 7th sector in particular being a longstanding Socialist working-class stronghold.

The election of FN municipal councillors in these targeted locations and elsewhere also facilitated the election of $459 \mathrm{FN}$ representatives to intercommunal councils ('intercommunalités'). In all, then, these elections must be seen as marking an important advance in the institutionalisation of the FN. They confirmed the stabilisation of the FN vote two years on from the legislative elections of 2012 and consolidated its place as the third party of France at local as well as national level. Most significantly, they allowed the FN to invest in an essential dimension of its growth strategy: the cultivation of local power bases.

These municipal elections, however, were far from constituting a 'seismic event' and did more to expose the FN's limitations than to demonstrate its strengths. Though it fielded a record 585 lists in communes of more than 1,000 inhabitants, this represented a very small proportion (6 per cent) of the 9,663 such communes across France. It was a figure rivalled by the much smaller Parti de Gauche, which also fielded close to 600 lists. Of the 317 run-offs it contested, the FN won only ten (having secured Hénin-Beaumont on the first round, its one outright gain from 203 councils won on the first round). Worryingly for the party's electoral strategists, it saw its aggregate support fall rather than rise between the two rounds, notably in three-way run-offs (Evans and Ivaldi, 2014a). Whereas some little known candidates surprised by the strength of their performance to secure their post as mayor, party heavyweights enjoying strong first-round leads such as Louis Aliot in Perpignan (34.2 per cent), Florian Philippot in Forbach (35.7 per cent) and Gilbert Collard in Saint-Gilles (42.6 per cent) failed to win their councils, while Marion Maréchal-Le Pen's list in Sorgues with 33.8 per cent went down to defeat by the centre-right Union pour un Mouvement Populaire (UMP) in the first round. These failures to deliver council majorities in relatively favourable locations underlined the weakness still of the FN's grassroots implantation and the limitations of deploying national 'notables' in local elections.

Looked at within the bigger picture of these elections, the FN's performance again spoke more of weakness than of strength. It won 11 towns of over 9,000 inhabitants out of more than 1,000 such towns $(1,081)$ across France - just one in 100. It secured 12 out of over 36,500 mayorships (one in 3,000), adding to the above 11 town halls the village of Le Hamel in the Oise department with its population of fewer than 200. Across the 585 municipal 
communes selected as most favourable by the FN, it won under 15 per cent of the vote and under 8 per cent of the seats with its 1,544 councillors out of over 20,000 at stake there (Evans and Ivaldi, 2014b) and over half a million at stake across the country as a whole. All of this must be seen as a poor return for a party polling historically up to 15 per cent in national elections. It provides a sharp corrective to the less than measured claim made in $L e$ Figaro that these municipal elections confirmed the FN's 'entrenchment across the entirety of France' (Galiero, 2014b).

The instructive comparison is not with the preceding municipal elections of 2008 , which marked a low point in the FN's fortunes following its heavy losses in the legislative elections of 2007 ( 4.3 per cent), but with those of 1995. Then, the party had run 490 lists and won control of the southern towns of Orange and Marignane (both with close to 30,000 inhabitants) as well as the major port of Toulon (with its population of 170,000), going on in 1997 to add the further medium-sized town of Vitrolles. Analysis of its performance in towns with over 30,000 inhabitants showed little progress over the twenty-year interim, between a 12.8 per cent share of the vote in 1995 and a 13.6 per cent share in 2014. In larger towns of over 100,000 inhabitants, there was even less progress, from 12 per cent in 1995 to 12.3 per cent in 2014 (Gougou and Persico, 2014). In terms of council seats won, too, there was improvement but not on a grand scale, from 1,249 seats won in 1995 to 1,544 in 2014, an increase of less than a quarter. And as a national percentage, the FN's 4.8 per cent in 2014 was on a par with its national score in 1995.

The 2014 elections can be most accurately seen, then, as a return to a level of municipal challenge predating the party split of 1999 which destroyed much of the FN's local infrastructure and drained a large part of its activist base. Though its well targeted performance in 2014 yielded more towns, comparison between the 1995 and 2014 municipal elections showed the uneven nature of the party's recovery from that damaging split. While regions of historic strength (Provence-Alpes-Côte d'Azur, Languedoc-Roussillon) and developing strength (Nord-Pas-de-Calais, Picardie, Champagne-Ardenne) saw the FN consolidate and reinforce its local presence, and while the party continued to extend patchily into 'terres de mission' in the west and south-west, other areas of FN strength in 1995 (Ile-de France, Rhône-Alpes, and to a degree Alsace) showed an FN vote in retreat in 2014. In some localities, the FN was unable to rebuild its activist base sufficiently to constitute electoral lists (Alidières, 2014). 
A more recent comparison with the legislative elections of 2012 also called into question the electoral dynamic of the FN in 2014. Analysis of the 2012 election results broken down by municipal commune showed a compound gain for the party of some 10 per cent in terms of votes cast in 2014; but the average difference in percentage share of the vote between the first rounds of the legislative and the municipal elections was almost nil, with marked gains in some locations offset by losses elsewhere (Evans and Ivaldi, 2014c). In some strongholds, the FN vote share dropped - by 5 percentage points in Saint-Gilles and 3 points in Sorgues, to cite just the two municipalities contested by the FN's parliamentary deputies, Gilbert Collard and Marion Maréchal-Le Pen, neither of whom succeeded in securing victory. Rather than an electoral dynamic, such results suggested at best a stalled progression in locations where the FN might have been expected to capitalise on ground previously gained.

This did not prevent Marine Le Pen from proclaiming 'the end of bipolarised politics' (Le Monde, 2014b) despite a configuration of results that clearly indicated the opposite. While the FN emerged from the first round with 4.8 per cent of the nationwide vote, the Union de la Droite, 'divers droite' and UMP took a combined 43 per cent and the Union de la Gauche, 'divers gauche' and PS 34 per cent. This picture of an overwhelmingly bipolarised political landscape was reinforced by the second round, with the FN taking 6.7 per cent of the overall vote against 44 per cent for the combined right and 39 per cent for the combined left (Interior Ministry, 2014a). Far from redrawing the political map, these elections merely laid bare the limited ambitions, resources and achievements of an FN unable to break the duopoly of the UMP and the PS at the heart of their respective centre-right and centre-left blocs.

\section{The European elections - a 'big bang'?}

Unlike the municipal elections of March, the European elections of May 2014 brought together a set of conditions highly favourable to the FN, contested as they were over a single round of voting on the basis of proportional representation. Perceived as 'second-order' elections with low national stakes, European elections have since their introduction in 1979 offered non-mainstream parties an opportunity to reap rewards in accordance with their vote share. It was the European elections of 1984 that saw the breakthrough of the FN as a national party with a vote share of almost 11 per cent and 10 MEPs. That breakthrough was 
followed by renewed successes in 1989 (11.7 per cent: 10 MEPs) and 1994 (10.5 per cent: 11 MEPs) before the split of the party in 1999 presaged a drop to 5.7 per cent of the vote and five MEPs (Shields, 2007).

The following elections of June 2004 were organised on a new basis less readily favourable to the FN. Whereas in previous European elections seats had been allocated proportionally on a national basis, the system introduced for these elections divided France into eight interregional constituencies with MEPs drawn proportionally from party lists in each. With 9.8 per cent of the vote overall, the FN took 7 seats yielded by five of these new constituencies. In the subsequent elections of 2009, after the collapse of the FN vote in the 2007 legislative elections, the party managed to secure only 6.3 per cent of the vote and three MEPs, its lowest return in 25 years of competing in these elections.

As the first European poll to be contested by the FN under the leadership of Marine Le Pen, the 2014 elections were seen as a test of how far the party could reverse this downward trend and build on its new momentum after the strong electoral recovery of 2012. Pre-election polls tipped the FN to perform more strongly than ever and maybe come first ahead of the UMP. In the event, the margin by which the FN did win this election exceeded even the most generous predictions. With 24.9 per cent of the vote, it finished well ahead of the UMP's 20.8 per cent and with almost double the score of the PS-led Union de la Gauche on just under 14 per cent. The closest lists thereafter were the Union du Centre with 9.9 per cent and Europe-EcologieLes Verts (EELV) with 8.9 per cent (Interior Ministry, 2014b).

This resounding victory, the FN's first in nationwide elections, gave the party 24 seats in the European Parliament (an eightfold increase on its 2009 showing) compared with the UMP's 20 and the Socialists' 13. It quadrupled its most recent European election vote tally of 1,091,691 in 2009 to 4,712,461, more than doubling its historically highest vote of 2.2 million in 1984 (Le Gall, 2014). This was the strongest vote count ever recorded by the FN as a party in any election, exceeded only by the presidential election scores of 2002 and 2012 , though far in advance of both in terms of percentage vote share.

Whereas in 2009 the FN had strained to win a seat in three of the eight Euro-constituencies, in 2014 it topped the poll in five of those constituencies - North-West (33.6 per cent), East (29 per cent), South-East (28.2 per cent), South-West (24.7 per cent) and Massif-Central 
Centre (24.2 per cent). Even in the west of the country, where the FN had never been strong, the Liste Bleu Marine - Non à Bruxelles, Oui à la France took 19.3 per cent of the vote. This was an extraordinary performance in a Euro-constituency where the FN had scored 5.6 per cent in 2004 and 3 per cent in 2009, confirmation of the party's success in pushing beyond its established strongholds in the north, north-east and south-east to set down roots in the 'terres de mission' of the west.

To be beaten into second place here by the UMP (19.6 per cent) with a margin of just 0.3 per cent was arguably the most arresting result of these elections. Completing the picture with 17 per cent and again a second-place finish after the UMP in Ile-de-France, a region where it had posted a score of 4.4 per cent in 2009 , the FN could claim in these elections to be the party of one in three to one in six voters throughout the length and breadth of metropolitan France. This was a claim buttressed by finishing first in 16 of the 22 metropolitan regions and in 71 of the 96 departments, scoring 30-40 per cent in 25 of these (Roger, 2014).

The factors playing in the FN's favour in these elections went beyond the party's newfound momentum and the opportunity offered by the proportional voting system. The elections were held exactly two years into the most unpopular presidency since records began, with François Hollande's campaign promises to offer an alternative to austerity, kickstart economic recovery and bring down unemployment translating into public spending cuts, a stalled economy and relentlessly rising joblessness. Whatever the dangers of historical reductionism, it was hard to resist memories of 1984 when Hollande's Socialist predecessor, François Mitterrand, and his first Prime Minister, Pierre Mauroy, plumbed the depths of unpopularity in a context of deepening economic recession and soaring unemployment that saw the first spike in support for the FN. Then, however, a relatively unknown FN had trailed in fourth after a powerful centre-right alliance on 43 per cent, a deeply implanted PS on over 20 per cent and a still viable Communist Party (PCF) on just over 11 per cent.

2014 was of a different order. The UMP and the PS both delivered their worst performance on record, while the PCF could claim only a portion of the 6.3 per cent mustered by the Front de Gauche and one of its three seats in the European Parliament. As in the March municipal elections, the FN's capacity to hurt centre-right and left alike was confirmed, with many of the party's gains being achieved in former strongholds of the left. The FN drew especially high support from voters hardest hit by economic recession who might once have turned 
more readily to a Socialist or Communist alternative. IPSOS polling showed support for the FN at 43 per cent among blue-collar workers, 38 per cent among low-skilled employees and 37 per cent among unemployed voters. Those with the poorest levels of education and the lowest incomes were most disposed to vote FN (37 per cent and 30-31 per cent respectively), while the party drew 8 per cent of those feeling closest to the PCF/Front de Gauche and 6 per cent of those who had voted for Hollande in the first round of the 2012 presidential election. Support for the FN also reached 30 per cent among voters aged under 35, those most exposed to a youth unemployment rate running close to 25 per cent and now twice as likely to vote for the FN as for the Socialists or the UMP, with other parties exerting an even weaker counterappeal among this age group (IPSOS, 2014).

In a context of sustained economic adversity, the Hollande administration's privileging of certain high-profile social issues (same-sex marriage and adoption, reform of the justice sytem) and its early attempts to address the deficit by raising taxes prompted a radicalisation of opposition from which the FN could only benefit (as borne out, it seemed, by the 15 per cent of Sarkozy's first-round voters from 2012 now drawn to Marine Le Pen's party). This radicalisation of opposition sparing neither governing Socialists nor centre-right was part of a wider anti-system, anti-elite groundswell that found expression in the Europhobia articulated by the FN in these elections. While the UMP and the PS played down their inherent support for the European Union (EU), in deference to their own internal oppositions, the FN gave full vent to an anti-EU discourse that clearly chimed with most of its voters, resonating with doubts over Brussels-led austerity economics and the virtues of open borders. With immigration, purchasing power, the euro zone crisis and unemployment the main issues at play in these elections, polling found 83 per cent of FN supporters judging France's EU membership to be worsening the effects of economic crisis, 58 per cent deeming it 'a bad thing', and 66 per cent wishing France to quit the euro zone and return to the franc (IPSOS, 2014).

The FN was the incontestable winner of these elections. Yet its apparently spectacular performance must be set in the context, first, of the elections themselves and, second, of the wider utility of its victory. With a near-record abstention rate of 57.6 per cent, the 24.9 per cent of the vote won by the FN equated to just 10.1 per cent of the electoral register. This was significantly better than the 6 per cent, 5.6 per cent and 5.2 per cent of registered voters attracted to the FN in its three previously strongest European election performances (1984, 
1989 and 1994), but it was barely an advance on the 9.6 per cent of registered voters who had supported the party in its legislative election high point of 1997, and it was well down on the 13.9 per cent of the electoral register secured by Marine Le Pen in the first round of the presidential election of 2012. It was also less than the 11.7 per cent of the electoral register won by Jean-Marie Le Pen in the presidential poll of 2002, the 11.4 per cent in 1995 and the 11.5 per cent as far back as 1988 . So, as a share of potential vote rather than actual vote, these European elections marked less of an unprecedented advance than appearances suggested.

Presidential elections under Jean-Marie Le Pen's leadership were viewed as opportunities to broaden support through a personal appeal that would then be transferred to the party. This never worked. Between presidential and ensuing legislative elections, the FN vote share invariably fell (-4.7 per cent in 1988, -5.7 per cent in 2002, -6.1 per cent in $2007,-4.3$ per cent in 2012). Measured against the 4.8 million votes won by Jean-Marie Le Pen in the first round of the 2002 presidential election, the 4.7 million votes won in the 2014 European elections not only showed no advance in more than a decade: they concealed a still less favourable comparison with the 6.5 million voters estimated to have voted for Le Pen in at least one of the two rounds in 2002 (Shields, 2007: 290). That same numerical pool would be recuperated by Marine Le Pen with her 6.4 million presidential votes in 2012, against which the 2014 European elections marked a loss of some 1.7 million - proof that presidential elections were still setting the bar too high for the party.

Part of that relative loss in 2014 is explained by the highly mobilising nature of presidential elections and the weaker mobilisation for other elections, most notably European. Poll findings showed that, of Marine Le Pen voters from 2012 who turned out for the European elections in 2014, 93 per cent voted FN. This was a much higher level of voter loyalty than that for any other party and suggested the consolidation of the FN electorate. Polls also found, however, that only 50 per cent of Le Pen voters from 2012 did vote in 2014 (IPSOS, 2014; OpinionWay, 2014). This failure to get more than one in two of its former voters out might be understood as a function of the political disenchantment on which the FN has sought to capitalise in growing its electorate; but it signifies, too, that disenchanted, politically pessimistic and negatively mobilised voters are not a reliably solid electoral corps.

This raises the question of the range of the FN's electoral appeal. The 'neither right nor left' strategy may have served the party well in bringing numbers of voters who reject the politics 
of the mainstream. In the European elections, the FN attracted 35 per cent of voters with no partisan attachment to any party of right or left; but only one registered elector in four (IPSOS, 2014) or five (OpinionWay, 2014) classing themselves in this category was estimated to have voted. So the FN managed to mobilise only a very small proportion of politically disengaged potential voters, the great majority being inclined instead to abstain.

In reaching out to both right and left, moreover, the FN was attempting to reconcile incompatibles. The annual TNS Sofres poll of February 2015 measuring support for the FN showed 85 per cent of UMP sympathisers favouring stronger measures to deal with petty crime, but only 18 per cent agreeing with the FN's core policy of withdrawal from the euro and return to the franc; it also showed 63 per cent support among left-leaning respondents for the defence of traditional values, falling to 23 per cent on another key FN policy, the restoration of capital punishment (TNS Sofres, 2015). Increasingly pronounced in the FN's policy agenda is a structural divide between an authoritarian social conservatism apt to resonate with more right-wing elements of the UMP - now renamed 'the Republicans' - and a statist, welfarist discourse reaching out to the economically vulnerable. This socially rightleaning, economically left-leaning appeal may not preclude a strong composite vote in the first round of elections; but, combined with the FN's enduring credibility deficit as a prospective party of government (TNS Sofres, 2015), it complicates the prospects for forming a winning majority in the second round.

Finally, if the measure of political success is what a party can do with its gains, the European elections of 2014 were a mitigated success only for the FN. Having pledged to storm the bastion of Euro-federalism and take back 'territorial sovereignty, monetary sovereignty and budgetary sovereignty' (Delaunay, 2013), Marine Le Pen's cohort of 24 MEPs soon found themselves little more than an irrelevance consigned to the margins of the European Parliament. Their failure initially to form a parliamentary group (requiring 25 MEPs from at least seven EU member states) reduced them to an informal alliance with similarly ostracised forces in the Dutch and Austrian Freedom Parties, the Belgian Vlaams Belang and the Italian Lega Nord.

Deprived of the financial, administrative and procedural benefits of having an official group, the FN had to watch as effective leadership of the anti-EU cause was assumed by Nigel Farage of the UK Independence Party (UKIP), who refused to countenance an alliance with 
the FN on the grounds that 'anti-Semitism and general prejudice remain[ed] in the DNA of the party' (Waterfield, 2013). Farage pressed ahead to form his Europe of Freedom and Direct Democracy (EFDD) group, a motley assortment of Italy's Five Star Movement, the Sweden Democrats, and parties from Lithuania, the Czech Republic and Poland. Rebuffed by the UKIP leader, Marine Le Pen had to endure the spectacle of his parliamentary group being made possible only by a defector from the FN, Joëlle Bergeron, who allowed the EFDD to claim representation from a seventh member state and thereby qualify as a formally constituted group. By contrast, Marine Le Pen's failed attempt in summer 2014 to put together a rival group was a step back from where the FN had been able to position itself at the start of a number of previous legislatures (1984-89, 1989-94, 1999-2004, 2004-09), when it had led parliamentary groups of different compositions and durations and weighed more significantly on the European parliamentary process. Though 'first party of France' the FN might claim to be in these most recent European elections, it was a boast that rang hollow in the corridors of Strasbourg.

\section{The Departmental elections - a 'political landscape in irreversible upheaval'?}

The departmental elections of March 2015 were to be the test of whether the FN could retain this lead position in elections with very different stakes and despite a return to the two-round majority voting system. These elections, involving 98 of France's 101 departments, inaugurated a new electoral map that redrew cantonal boundaries, cutting their number from 4,035 to 2,054 . The other major innovation was the introduction of male-female tandems ('binômes') designed to give exact parity for the first time to election outcomes. With two candidates per party seeking election in 2,054 cantons, a total of 4,108 seats were at stake across the new departmental councils ('conseils départementaux') designated to replace the general councils ('conseils généraux') that had formerly served as the departmental governing bodies.

Polling 5,142,177 votes, the FN took 25.2 per cent of the ballot nationally, on a 50.2 per cent turnout, but fell short of predictions that it would win the first round with a score possibly in excess of 30 per cent. The UMP and its centrist allies totalled 29.4 per cent of the vote, with the Socialists and their Union de la Gauche allies coming third on 21.5 per cent and the Front de Gauche far behind on 4.7 per cent. 
Compared with less than 5 per cent in the 2008 cantonal elections and 15 per cent in those of 2011, there could be no doubting the dynamic behind the FN's performance in 2015. That dynamic was reflected in part through the number of cantons contested by an FN that had always found this an almost impossible electoral level on which to make an impact. Having fielded candidates in 1,035 cantons in 2008 and 1,441 in 2011, it had won not a single seat in 2008 and only two in 2011 (Gougou and Labouret, 2011: 387). In 2015, the FN contested 1,909 of the 2,054 cantons at stake, fielding a total 3,818 candidates in line with the gender parity 'binôme' system imposed for these elections. With the requirement to nominate reserves ('suppléant' and 'suppléante') for each pair of candidates fielded, the FN's slate comprised fully 7,636 candidates and reserves, larger than that of the UMP, the Socialists and all other parties.

These elections set a new record for the FN as a party both in terms of ballot share and number of votes, its 5.1 million votes (12 per cent of the electoral register) exceeding the 4.7 million (10.1 per cent of the electoral register) won at the European elections of May 2014. It came first in 43 of the 98 departments involved, performing strongly in traditional bastions of the south - Var (38.9 per cent), Vaucluse (37.4 per cent), Gard (35.5 per cent) - and developing strongholds of the north - Aisne (38.7 per cent), Pas-de-Calais (35.6 per cent), Oise (35.1 per cent), Haute-Marne (35.1 per cent). Again, as in the European elections, there was ample evidence of the FN's penetration of departments in the centre and west, with 26.4 per cent in Sarthe, 24.9 per cent in Cher, 24.6 per cent in Charente-Maritime, 23.4 per cent in Indre-et-Loire, 22.6 per cent in Vendée, 22 per cent in Maine-et-Loire, and even a canton (Nord-Médoc) gained in the south-western Gironde (Interior Ministry, 2015).

FN scores were particularly strong in locations where the party had secured mayors in 2014. In Le Pontet in the Vaucluse, the suspended FN mayor Joris Hébrard and his tandem partner Danielle Brun won election at the first round despite the invalidation of the municipal election result on grounds of procedural irregularity (Le Monde, 2015). The FN also won with first-round majorities in the cantons of Fréjus (Var), Vic-sur-Aisne (Aisne) and EurvilleBienville (Haute-Marne), going on to win run-offs in Beaucaire, Villers-Cotterêts, both cantons of Hénin-Beaumont and all three cantons of Béziers. These results in fiefdoms of FN mayors were a strong vindication of Marine Le Pen's strategy of building from the base and 
consolidating local gains through interlinking elections, with many of the municipal councillors elected in March 2014 contesting cantonal seats in 2015.

In all, the FN won 31 cantons, sending 62 councillors into 14 of France's departmental councils. Within its own limited terms, this was a resounding success for a party that had never at any time held more than three of the 4,035 cantonal seats previously available, even if it lost the single canton of Brignoles (Var) with which it went into these elections. It gave evidence of the FN's growing ability in certain locations to prevail not just against divided opposition in three-way run-offs but against more concerted opposition in two-way run-offs with both centre-right (Béziers-2, Villers-Cotterêts) and left (Beaucaire, Béziers-1, Béziers-3, Hénin-Beaumont-1, Hénin-Beaumont-2). In other locations with FN mayors where the party failed to win the canton (Cogolin/Sainte-Maxime, Le Luc, Hayange), it nonetheless held its majority at the municipal commune level, showing that here too support was consolidated. All of this chimed with an IFOP poll of March 2015 showing levels of satisfaction with mayors one year on from the municipal elections to be markedly higher (at 73 per cent on average) among respondents under FN governance than among those under mayors from other parties (Gaboulaud, 2015).

A sociological survey of these elections by OpinionWay confirmed much that now defines the FN vote. It showed strong support among blue-collar workers (47 per cent), low-skilled employees (34 per cent), unemployed voters (31 per cent), those on short-term or precarious work contracts (33 per cent), and social housing tenants (34 per cent). Low educational attainment and low income were again strong predictors of an FN vote (with 41 per cent and 33 per cent of these categories drawn to the party), as was lack of faith in right or left to govern (38 per cent) and a desire for greater protectionism (50 per cent). Though these were local elections with local stakes, the FN vote was once again marked by a strong antiEuropeanism, with the party drawing support from 65 per cent of respondents judging France's membership of the EU to be 'a bad thing' and 67 per cent of those wishing France to abandon the euro and return to the franc (OpinionWay, 2015).

A simple arithmetical question hung over the results of the first round. Had the FN repeated its feat of May 2014 to finish first or had that claim passed, as widely reported, to the UMP? The breakdown of voting as published by the Interior Ministry was incontrovertible (Laurent, 2015; Pouchard, 2015a). Votes cast for candidates running on specific party labels, once 
extricated from the compound voting for 'binomes', confirmed that the FN had topped the first round with its 5.1 million votes, ahead of the PS (3.3 million) and the UMP (3.2 million). It also topped the second round with 4 million votes, ahead of the UMP on just under 4 million and the PS on 3.6 million. The strength of the UMP's performance in these elections came both from votes cast for UMP candidates and from its alliance with the centrists of the UDI and in part MoDem. That alliance allowed the combined centre-right and centre to be the first political force in France, but it did not make the UMP the first party in these elections, a claim to which the FN continued to hold with some justification.

This poses, again, a bigger question. What good is finishing 'first' if a party can do little or nothing with that success? Despite totalling over a quarter of the vote in the first round $(25.2$ per cent) and close to a quarter in the second (22.2 per cent), the FN was systematically squeezed out of almost all of the 1,107 run-offs it contested, including the 320 cantons where it led the poll at the first round. It averaged some 35 per cent of the vote in those cantons where it was present in the second round, with scores of 45-50 per cent in almost a hundred of them (Le Point, 2015). But the hard reality was that it won only 22 of 834 two-way runoffs (19 against the left and three against the centre-right) and only five of 273 'triangulaires', where it should have expected to perform more effectively against divided opposition.

In all, the FN managed to harness only 1.5 per cent of the seats across the departmental councils of France $(62$ out of 4,108$)$ and failed to generate a critical mass of support within any department to win control. Here again was a graphic demonstration of the withering effects upon the FN of two-round majority voting, given its isolation within the party system and the consequent difficulty of increasing sufficiently its reservoir of support between the rounds in all but a few places. The Aude department in the southern Languedoc-Roussillon region provided a classic illustration. There the FN scored 33.7 per cent in the first round and 39 per cent in the second, but it won not a single cantonal seat out of 38 ( 32 of them going to a PS that had trailed the FN on 32.1 per cent in the first round but, crucially, could extend beyond that base to average 44.6 per cent in the second).

Even in those departments where the FN had hoped at least to play a determining role in the election of council presidents (Aisne, Vaucluse, Gard), it did not in the end exert any decisive impact. As a preliminary to potential agreements with the UMP, it issued a 'charter' with a 
set of non-negotiable conditions, pledging itself against council tax rises, the reduction of local public services, welfare benefit fraud, the wearing of the Islamic headscarf in crèches, and subsidies for multicultural associations or projects (Front National, 2015). In the Gard, the centre-right chose to cede control of the council to the Socialists rather than sign up to these conditions; in Aisne, the UDI took control with a relative majority, again rather than enter agreement with the FN; and in the Vaucluse, stalemate was resolved by a centre-right president being elected on grounds of age (a procedural provision) rather than through any deal with the FN.

By the end of this so-called 'third round' to elect council presidents, the UMP controlled 45 departments, the UDI 14, the 'divers droite' seven and MoDem one, while the PS controlled 26, the Left Radicals three, the 'divers gauche' three, the Front de Gauche one, and a 'divers' alliance one (Pouchard, 2015b). Correlating these outcomes with ballot share in both rounds underlined the disproportionality of the electoral system, as did the final distribution of council seats across all departments, with 1,138 for the UMP, 1,008 for the PS and 379 for the UDI set against 62 for the FN. Even the Front de Gauche, with 6.1 per cent then 2 per cent of the vote over both rounds, took 156 seats while the PCF retained control of the department of Val-de-Marne (Pouchard, 2015a).

Far from presaging, in Manuel Valls's words, a 'political landscape in irreversible upheaval' (Libération, 2015), these elections marked a return to politics as usual, with the swing from a left-dominated (61/40) departmental map to a right-dominated (67/34) one being the overriding story. After a first round that appeared to confirm the shift from a two-bloc to a three-bloc system, the bipolarisation that had defined electoral competition throughout the Fifth Republic returned with all its implacable logic. There were in effect two elections here: one to determine electoral strength, the other to distribute executive power and influence within governing councils. The first, as the FN found once again, is reduced to abstraction if it does not lead to concrete outcomes in the second.

\section{The FN and French political space: bipolarised or tripartite?}

'Can the Front National come to power?', asked Alexandre Dézé (2012: 157) in his historical survey of the party's evolution. Can the FN 'gain sufficient ground to overturn the political 
system?', reflected Pascal Perrineau (2014: 215) in his more recent review of the party's progress. The two questions are of a piece. For it is only by disrupting the established model of party politics in France, 'overturning the political system' and - crucially - the bipolarising imperatives that govern electoral competition, that the FN can nurture the prospect of acceding to power.

This returns us to a debate that has divided analyses of French politics between those arguing for a realignment of political space into a three-bloc party system (Grunberg and Schweisguth, 2002, 2003) and those wedded to bipolarisation as the fundamental, enduring structural model (Andersen and Evans, 2003). That both positions have a strong rationale to commend them, and that analysts can move from one interpretation to the other as the evidence of the moment dictates (Grunberg and Haegel, 2007), shows the difficulty of seeking a definitive resolution to this question (de Voogd, 2014; Revault d'Allonnes, 2015; Hausalter, 2015). A central argument of this article has been that, as they relate to the electoral process, both readings have their place, with the tripartition of French politics between left, centre-right and FN finding expression in the first round of elections and bipolarisation asserting all its traditional dominance in the second. Put another way, the FN has managed to break down the bipolarised structure of French electoral competition to a point - but only to a point.

In addition to first-round voting, election run-offs staging three-way (left/centre-right/farright) contests might be expected to serve as some measure of a tripartite structure in French politics. Given the difficulty of mustering the absolute majority required to prevail in twoparty run-offs, second-round 'triangulaires' should offer the FN opportunities to secure victory through a relative majority only and to impose itself as a viable rival to the mainstream blocs. Yet the record of the FN's performance in such 'triangulaires' is extremely poor, demonstrating not any newly entrenched three-way model of French party politics but, once again, its enduring bipolarisation. Of 28 'triangulaires' contested in the 2012 legislative elections, the FN won only two; of 273 contested in the 2015 departmental elections, it won five (finishing second in 54 and third in 214). Though the 'Republican front' between left and centre-right in run-offs against the FN no longer functions as a rule, other factors (increased voter turnout, tactical voting, erosion of FN support) combine to favour left-right bipolarisation to the almost invariable exclusion of the FN (Delwit, 2012: 141-142; Evans and Ivaldi, 2013: 178-179). 
So where does this leave the FN in its ambitions and prospects? When Marine Le Pen was elected leader at the party's national congress in Tours in January 2011, she was clear about the significance of the moment. This was, she declared, the start of her party's 'irresistible rise to power' (Le Pen, 2011). A rhetorical imperative upon an incoming party leader perhaps, but her words signalled a fundamental change in the purpose of the FN. Under JeanMarie Le Pen, the FN had been defined by its outsider status, a nuisance party whose ambitions were restricted to the electoral arena, privileging vote-maximisation over officeseeking. It engaged symbolically in a strategy for winning power (preparing for 'government' as far back as its Nice Congress of 1990 under the slogan 'The conquest of power'); but its comfort zone was one of perennial opposition. The party's one significant experience of local office in the 1990s led to an acrimonious split between those, under Bruno Mégret, committed to making the FN a party of government and those, under Jean-Marie Le Pen, content to perpetuate its role as a party of protest (Shields, 2007: 275-281).

Since becoming leader, what has Marine Le Pen achieved through her cultivation of a more modern and moderate party image allied to a new 'strategy for winning power' (Le Pen, 2011)? She has overseen a sharp rise in the party's first-round vote share nationally across a range of elections: from 10.4 to 17.9 per cent in presidential elections, 4.3 to 13.6 per cent in legislative, 0.9 to 4.8 per cent in municipal, 6.3 to 24.9 per cent in European, and 4.8 to 15 per cent then 25.2 per cent in cantonal/departmental elections. These results attest to a strong electoral dynamic that has moved the FN forward in terms of vote-maximisation, but have they brought the party any closer to office? Only the municipal elections of 2014 yielded tangible gains in terms of executive power, but these were both severely limited and far from unprecedented, reminiscent of advances made two decades before in the municipal elections of 1995.

The elections of 2014 and 2015 were not transformational: they were a reaffirmation of the status quo. In terms of electoral representation at the various levels of governance in France, the FN still barely exists. The series of elections since 2011 brought it two National Assembly deputies out of 577 (to which it added in September 2014 two senators out of 348), 1,544 municipal councillors out of 519,417, and 62 departmental councillors out of 4,108. As a presence within these elected assemblies, the $\mathrm{FN}$ occupies 0.4 per cent of parliamentary seats across both houses, 0.3 per cent of municipal council seats and 1.5 per cent of 
departmental council seats. The only elections run on full proportional representation which returned seats to the measure of the party's vote ( 24 of the 74 allotted to France in the European Parliament) came to nothing in real terms when the FN failed to form a parliamentary group through which to make its presence felt in Strasbourg. The belated formation of that group in June 2015 gave the FN and its allies more resources and more prominence within the European Parliament but did not alter in any way the balance of real power there.

Both the European elections and the departmental elections raised the question therefore of what being the 'first' party of France means. Counting votes in a particular election is one narrow method of asserting this, but there are other methods too. The PS, for all its tribulations in government, enjoys an unshakeable hold on the levers of national power; across all levels of subnational governance too, it is still the party with the largest combined number of elected officials, ahead of the Republicans then the UDI. By this measure, the FN emerges not as the first party but as the sixth. Then there is the dominance of the Republicans across the municipal and departmental maps of France, where they exert control over broadly two-thirds of town and country. This is a scale on which the FN barely registers, coming eighth in the list of parties or groupings represented in France's departmental councils, with 18 times fewer seats than the Republicans and 16 times fewer than the PS (Pouchard, 2015a). And while only the Republicans and the PS have any realistic prospect of winning France's two key electoral prizes, the presidency and the National Assembly, Marine Le Pen would achieve no more in real terms by getting to the presidential run-off in 2017 , if poll predictions are borne out, than her father did in 2002.

We are left, then, with a party that has since 2011 advanced further and faster down the route set for it by Jean-Marie Le Pen (winning votes), but that has yet to gain traction on the route set by Marine Le Pen (winning representation leading to power). In an interview with $L e$ Monde in March 2014, the FN leader declared that what the party most needed was a record in office to demonstrate its governing competence (Mestre and Monnot, 2014). The towns won in March 2014 were a modest local start, but the elections of 2015 showed that winning a single department out of 98 at stake was still beyond the FN. France may, as Pascal Perrineau asserts, have entered 'a new chapter in its political history' with three major competing forces now at work (Cordelier, 2015); but it will take more than isolated successes 
to break the bipolarising mould within which electoral competition continues to favour the established parties of government over a tenacious but still critically hampered FN.

\section{References}

Akkerman, T. (2011) Friend or foe? Right-wing populism and the popular press in Britain and the Netherlands. Journalism 12(8): 931-945.

Alidières, B. (2014) Trois décennies de vote Front National: éléments pour une cartographie diachronique et multiscalaire. Institut Français de Géopolitique, http://www.geopolitique.net/en/actualites/actualites-de-linstitut/trois-decennies-de-vote-frontnational-par-bernard-alidieres-3.

Andersen, R. and Evans, J.-A. (2003) Values, cleavages and party choice in France, 19881995. French Politics 1(1): 83-114.

Boomgaarden, H.G. and Vliegenthart, R. (2007) Explaining the rise of anti-immigrant parties: The role of news media content. Electoral Studies 26(2): 404-417.

Bos, L., van der Brug, W. and de Vreese, C. (2011) How the media shape perceptions of right-wing populist leaders. Political Communication 28(2): 182-206.

Bretton, L. (2015) Pour Manuel Valls, le Front National est 'aux portes du pouvoir' dès 2017. Libération, 8 March.

Brouard, S. and Foucault, M. (2014) Municipal elections 2014: an estimation of the FN's results. 500 Signatures, 17 March 2014, http://500signatures.net/.

Cordelier, J. (2015) Départementales - Pascal Perrineau: 'Nous vivons un nouveau chapitre de notre histoire politique'. Le Point, 25 March.

Crépon, S. (2012) Enquête au coeur du nouveau Front National. Paris: Nouveau Monde.

Delaunay, N. (2013) Marine Le Pen et Gert Wilders unis contre l'Union européenne. Agence France Presse, 14 November.

Delwit, P. (2012) Le Front national et les élections. In P. Delwit (ed.) Le Front national. Mutations de l'extrême droite française. Brussels: Editions de l'Université de Bruxelles, pp. 113-142.

Dézé, A. (2012) Le Front national: à la conquête du pouvoir? Paris: Armand Colin.

de Voogd, C. (2014) Tripolarité? Mais nous y sommes depuis vingt ans! Le Monde, 27 March.

Ellinas, A.A. (2014) The Media and the Far Right in Western Europe: Playing the Nationalist Card. Cambridge: Cambridge University Press. 
Evans, J. and Ivaldi, G. (2013) The 2012 French Presidential Elections: The Inevitable Alternation. Basingstoke: Palgrave Macmillan.

Evans, J. and Ivaldi, G. (2014a) Wrapping it up: a final take on the FN in the 2014 municipals. 500 signatures, 2 April, http://500signatures.net/.

Evans, J. and Ivaldi, G. (2014b) Forecast of FN municipal seats. 500 signatures, 21 March, http://500signatures.net/.

Evans, J. and Ivaldi, G. (2014c) Taking stock of the Front National's performance in the municipal elections. 500 signatures, 26 March, http://500signatures.net/.

Fourquet, J. (2008) L’érosion électorale du lepénisme. In: P. Perrineau (ed.) Le vote de rupture. Les élections présidentielle et législatives d'avril-juin 2007. Paris: Presses de la Fondation Nationale des Sciences Politiques, pp. 213-234.

Fressoz, F. (2014) La poussée du FN aux municipales, un séisme politique? Le Monde, 24 March.

Front National (2015) Charte d'engagement politique pour le département, http://www.frontnational.com/2015/03/charte-dengagement-politique-pour-le-departement/.

Gaboulaud, A. (2015) Un an après, un premier bilan des maires FN. Paris Match, 12 March.

Galiero, E. (2014a) Le Front national crée le choc du premier tour et ancre son implantation. Le Figaro, 24 March.

Galiero, E. (2014b) Municipales 2014: Marine Le Pen gagne son pari en remportant treize mairies. Le Figaro, 31 March.

Garat, J.-B. (2014) La victoire du Front national provoque un séisme politique. Le Figaro, 26 May.

Gougou, F. and Labouret, S. (2011) The 2011 French cantonal elections: The last voter sanction before the 2012 presidential poll. French Politics 9(4): 381-403.

Gougou, F. and Persico, S. (2014) Les résultats du Front National au premier tour des élections municipales de 2014: un retour en 1995. Slowpolitix, 27 March, http://slowpolitix.blogspot.co.uk/2014/03/les-resultats-du-front-national-au.html.

Grunberg, G. and Haegel, F. (2007) La France vers le bipartisme. Paris: Presses de la Fondation Nationale des Sciences Politiques.

Grunberg, G. and Schweisguth, E. (2002) La tripartition de l'espace politique. In: P. Perrineau and C. Ysmal (eds.) Le vote de tous les refus. Paris: Presses de la Fondation Nationale des Sciences Politiques, pp. 341-362.

Grunberg, G. and Schweisguth, E. (2003) French political space: Two, three or four blocs? French Politics 1(3): 331-347. 
Hausalter, L. (2015) Pourquoi le tripartisme aura du mal à s'installer en France. Slate.fr, 24 March.

Interior Ministry (2014a) Résultats des élections municipales et communautaires 2014, http://www.interieur.gouv.fr/Elections/Lesresultats/Municipales/elecresult_MN2014/(path)/MN2014/FE.html.

Interior Ministry (2014b) Résultats des élections européennes 2014, http://www.interieur.gouv.fr/Elections/Lesresultats/Europeennes/elecresult_ER2014/(path)/ER2014/index.html.

Interior Ministry (2015) Résultats des élections départementales 2015, http://www.interieur.gouv.fr/Elections/Lesresultats/Departementales/elecresult_departementales-2015/(path)/departementales2015/index.html.

IPSOS (2014) Elections européennes 2014 - comprendre le vote des Français, http://www.ipsos.fr/sites/default/files/attachments/europeennes_ipsos__comprendre_le_vote_des_francais___25_mai_2014___20h.pdf)

Jaxel-Truer, P. and Wieder, T. (2014) Le séisme qui ébranle la vie politique française. Le Monde, 27 May.

Kallis, A. (2013) Far-right 'contagion' or a failing 'mainstream'? How dangerous ideas cross borders and blur boundaries. Democracy and Security 9(3): 221-246.

La Tribune (2014) La presse étrangère sous le choc de la percée du FN aux municipales. 24 March.

Laurent, S. (2015) Départementales: qui a vraiment gagné le premier tour? Le Monde, 26 March.

Le Figaro (2014) Européennes 2014: Mélenchon déçu par son score. 25 May.

Le Gall, G. (2014) Les élections européennes du 25 mai 2014 en France: prolégomènes à 2017? Revue politique et parlementaire 1071-1072: 84-114.

Le Monde (2014a) Le triomphe du Front national dévaste le paysage politique français. 27 May.

Le Monde (2014b) Municipales: Marine Le Pen se félicite d'un 'cru exceptionnel pour le FN'. 23 March.

Le Monde (2015) L'annulation de l'élection du maire FN du Pontet validée. 25 February.

Le Pen, M. (2011) Discours d'investiture. Congrès de Tours, 15-16 January.

Le Point (2015) FN: un scrutin de mauvais augure pour la présidentielle. 30 March. 
Libération (2015) Manuel Valls: 'Un bouleversement durable de notre paysage politique'. 29 March.

Lichfield, J. (2014) 'Thunderclap' in French politics as National Front looks set to capture half a dozen town halls. The Independent, 24 March.

Mazzoleni, G., Stewart J. and Horsfield, B. (eds.) (2003) The media and neo-populism: A contemporary comparative analysis. Westport, CT: Praeger.

Mestre, A. and Monnot, C. (2014) Marine Le Pen: 'Ce qui nous manque, c'est un bilan'. Le Monde, 28 March.

Mondon, A. (2014) The Front National in the twenty-first century: From pariah to republican democratic contender? Modern and Contemporary France 22(3): 301-320.

Mondon, A. (2015) Populism, the 'people' and the illusion of democracy - The Front National and UKIP in a comparative context. French Politics 13(2): 141-156.

Oliveau, T. (2014) 'Choc', 'séisme', 'big bang': les mots qui accompagnent la victoire du FN. Le Figaro, 26 May.

OpinionWay (2014) Elections européennes 2014: sur quels critères les Français ont-ils voté? http://www.opinion-way.com/pdf/opinionway_pour_le_figaro_-_sondage_jour_du_vote__elections_europeennes_2014.pdf.

OpinionWay (2015) La sociologie du vote au premier tour des élections départementales 2015, http://www.opinion-way.com/pdf/7-opinionway_pour_1_opinion__la_sociologie_du_vote_au_premier_tour_des_el....pdf.

Perrineau, P. (1993) Le Front national, la force solitaire. In: P. Habert, P. Perrineau and C. Ysmal (eds.) Le vote sanction. Les élections législatives des 21 et 28 mars 1993. Paris: Département d'Etudes Politiques du Figaro/Presses de la Fondation Nationale des Sciences Politiques, pp. 137-159.

Perrineau, P. (2003) La surprise lepéniste et sa suite législative. In: P. Perrineau and C. Ysmal (eds.) Le vote de tous les refus. Les élections présidentielle et législatives de 2002. Paris: Presses de la Fondation Nationale des Sciences Politiques, pp. 199-222.

Perrineau, P. (2014) La France au Front. Essai sur l'avenir du Front national. Paris: Fayard.

Pouchard, A. (2015a) Après les départementales, quel est le premier parti de France? Le Monde, 31 March 2015.

Pouchard, A. (2015b) Qui sont les nouveaux présidents de départements? Le Monde, 2 April 2015.

Revault d'Allonnes, D. (2015) Faire rentrer trois dans deux, ou le tripartisme à la française Le Monde, 7 April.

Roger, P. (2014) Européennes: le FN arrive en tête dans 71 départements. Le Monde, 26 May. 
Rouart, J.-M. (2014) Le Front National, premier parti de France. Paris Match, 1 June.

Shields, J. (1997) La politique du pire: The Front National and the 1997 legislative elections. French Politics and Society 15(3): 21-36.

Shields, J. (2007) The Extreme Right in France: From Pétain to Le Pen. London: Routledge.

Tiberj, V. (2013) Values and the votes from Mitterrand to Hollande: The rise of the two-axis politics. Parliamentary Affairs 66(1): 69-86.

TNS Sofres (2015) Baromètre d'image du Front national, http://www.tnssofres.com/sites/default/files/2015.02.16-baro-fn.pdf.

Walgrave, S. and de Swert, K. (2004) The making of the (issues of the) Vlaams Blok: The media and the success of the Belgian extreme-right party. Political Communication, 21(4): 479-500.

Waterfield, B. (2013) Geert Wilders invites Nigel Farage to join anti-EU alliance. The Telegraph, 13 November.

Ysmal, C. (1989) Les partis politiques sous la Ve République. Paris: Editions Montchrestien. 